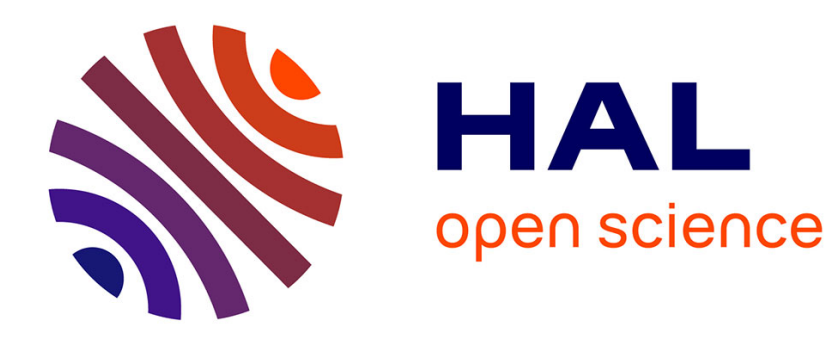

\title{
Excited states dynamics of Er3+ pairs in C sCdBr3
}

F. Pellé, Ph. Goldner

\section{To cite this version:}

F. Pellé, Ph. Goldner. Excited states dynamics of Er3+ pairs in C sCdBr3. Journal de Physique IV Proceedings, 1994, 04 (C4), pp.C4-604-C4-604. 10.1051/jp4:19944154 . jpa-00252610

\section{HAL Id: jpa-00252610 https://hal.science/jpa-00252610}

Submitted on 1 Jan 1994

HAL is a multi-disciplinary open access archive for the deposit and dissemination of scientific research documents, whether they are published or not. The documents may come from teaching and research institutions in France or abroad, or from public or private research centers.
L'archive ouverte pluridisciplinaire HAL, est destinée au dépôt et à la diffusion de documents scientifiques de niveau recherche, publiés ou non, émanant des établissements d'enseignement et de recherche français ou étrangers, des laboratoires publics ou privés. 


\title{
Excited states dynamics of $\mathrm{Er}^{3+}$ pairs in $\mathrm{CsCdBr}_{3}$
}

\author{
F. PELLÉ and Ph. GOLDNER
}

LPCM, CNRS, 92190 Meudon, France

$\mathrm{CsCdBr}_{3}$ is a very convenient host to study pair dynamics because trivalent impurities enter it nearly only as charge compensated dimers. This peculiar structure also enhances energy transfers involving two ions and especially APTE processes.

We have studied $\mathrm{Er}^{3+}$ anti-Stokes violet and UV emissions under various visible excitations which involved several mechanisms.

First; excitation in the ${ }^{4} S_{3 / 2}, 4 F_{7 / 2}$ or ${ }^{4} F_{5 / 2}$ levels results in efficient antiStokes emissions between 25300 and $32600 \mathrm{~cm}^{-1}$. Up-conversion is due to an energy transfer in symmetric pairs $\left(E r^{3+}-V a c a n c y-E r^{3+}\right)$ which are the dominant center in this compound. However, ${ }^{4} G_{9 / 2}$ and ${ }^{4} G_{11 / 2}$ fluorescence decays can not be explained by simple relaxation schemes.

Then, in order to determine the mechanisms of up.conversion under these different excitations, transients of ${ }^{4} D_{5 / 2}$ and ${ }^{4} G_{9 / 2}$ levels, which are difficult to reach directly, have been studied using Excited State Absorption in the ${ }^{4} F_{8 / 2}$ state. Detailed excitation spectra have also been recorded for these high energy levels and energies of these multiplets have been precisely established.

Finally, these results enabled us to model the fluorescence transients obtained under single color excitation. This analysis is based on competing relaxations in erbium dimers which are very efficient in this system. 